\title{
German professors appeal their dismissals in purge of thousands with ties to Stasi
}

Leipzig. Hundreds of university academics are appealing against their dismissals as part of the restructuring of the university system in the former East Germany. They have been judged by state commissions to be unfit for academic life because of allegations that they collaborated with the Stasi, East Germany's secret service, or used their Communist

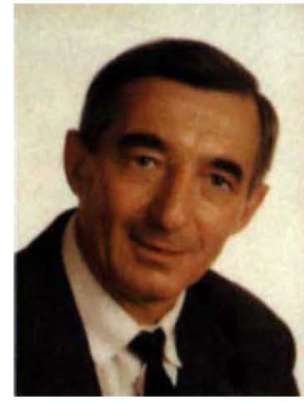

Armin Ermisch Party connections to influence the careers of colleagues or students. But some of the dismissals appear instead to be a form of revenge by colleagues with personal grievances.

The academics are pursuing their struggle individually, with no umbrella organization to protect their interests. But western scientists have lent their voices to defend Armin Ermisch, a professor of cell biology at the University of Leipzig, against reprisals for actions that, under normal circumstances, would have been considered perfectly appropriate.

Ermisch, whose international publication record in the past decade is well above average, has never hidden his early enthusiasm for communism, which he saw as the best possible option for post-war Germany. Neither does he hide his subsequent disillusion with the system or the fact that he chose to work from within to reform it. But he says that he never abused his status as a party member.

Ermisch has asked the state ministry to provide examples of actual wrongdoing, believing that committee members are reacting not to his politics but rather to the rigorously applied criteria of excellence which he enforced in his department. Those judged by Ermisch to be second-rate researchers were not promoted; unfortunately for him, these are now the people with power.

Immediately after reunification, Ermisch won an overwhelming vote of confidence in the university's first free and secret ballot. Yet only a year later he was kicked out as department chairman. "It was the worst day of my life", he says.

At a brief hearing in April, he was accused of being a member of the party and 'influencing the development of staff' in his section, 'influencing the education' of the students and providing information to Stasi 'on request'. In August he was given notice of dismissal from the university by the state ministry of science and arts. Ermisch hopes that a court will hear his appeal before the end of this year, when his contract of employment expires. But a date next year is more likely, making remote the prospect of reinstatement.

Ermisch's cause is one of the few to reach the outside world. Foreign collaborators who have spent time in Leipzig have written open letters of support protesting about his treatment. John Russell, of Edinburgh University's physiology department, says that the commission's refusal to allow cross-examination of witnesses at the hearing is an assault on democracy, and he casts doubt on the motives of Ermisch's critics: "Old scores may very well be being settled here", he says.

There are hun-

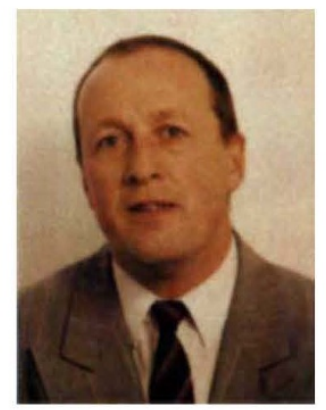

Wolf-Dietrich Arnold dreds more in the same position. Wolf-Dietrich Amold of the University of Leipzig's Orthopedic Clinic joined the Communist Party in 1985 because he believed it essential for a position he was offered as director of a large clinic in East Berlin. Ironically, he never took up the post, accepting instead a directorship created for him in Leipzig. Following a vote of confidence by his colleagues at the clinic, he worked normally and productively for two years. A hearing in July this year apparently went well, but his notification of dismissal in August came as a shock, and he was told to leave by the end of the year.

Arnold, one of 15 clinical professors at the clinic appealing against their removal for political reasons, has an impressive record of research on spinal injury, is known internationally and has received many job offers from other countries. He doesn't want to leave Germany and "live the life of a stranger", but he may have to if he cannot find work. He says that the official reasons for his dismissal are spurious and that a member of the commission that Arnold declined to promote has swung sentiment unfairly against him.

This belief is shared by at least one member of the commission, who has written in protest to the state research minister, Hans-Joachim Meyer. Arnold's lawyer, Friedel Schnur, representing all the clinical professors who were dismissed, says that such a letter is not unusual.

Dismissals for reasons of 'personal integrity' are part of a broad package of staff redundancies and reorganizations in East Germany following reunification in November 1989. With universities chronically overstaffed, a sizeable number of dismissals were expected. Many professors were made redundant to save money, while others were found not to be qualified for their positions by evaluation committees made up of scientists from both eastern and western Germany.

Although the dismissals on grounds of incompetence caused disruption and unhappiness, they drew no strong charges of unfairness. The controversy surrounding those set up to judge political pasts reflects the more subjective nature of the investigations. Although the system is designed to be fair, in practice it is shadowy. And because exact figures are hard to come by, the extent of the problems is not known.

Responsibility for education is decentralized in Germany, and each of the five former east German states developed its own approach to restructuring under a directive outlined in the 1990 reunification contract. The general procedure involves the establishment by the local

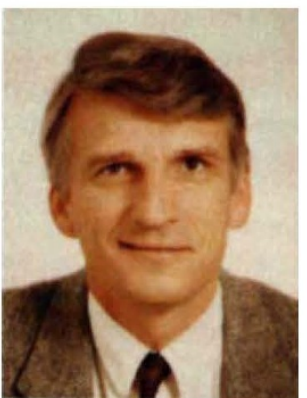

Hans-Ulrich Mönnig science and education minister of small commissions to consider the "personal integrity' of all professors and departmental chairpersons at a university, as well as others in positions of power. Known as 'Personal-

kommissionen', these commissions have been conducting formal 'hearings' that, along with information from colleagues and from Stasi files, result in recommendations to the minister. The minister has sole responsibility for the final decision; the federal government is not involved.

The process attempts to be fair. The commissions usually include a reasonable cross-section of the academic community and the public. A commission will typically include two or three university professors, a lecturer and a student, along with a couple of professors from the west and, in many cases, relevant public figures. Some states allow universities to make the appointments, while others assign the task to the state minister. 
But the lack of openness creates the opportunity for injustice, and although the decision can be appealed, a reversal in court does not necessarily guarantee reinstatement. A lengthy backlog of pending cases means that most of the vacated jobs will already have been filled. Even if reinstatement were offered, a lingering hostility may make working conditions intolerable. A more likely outcome of a successful appeal is monetary compensation.

In Sachsen, with the highest concentration of higher education institutes, about 1,000 academic staff have been dismissed for reasons of 'personal integrity'; nearly half have already left. Leipzig-based solicitor Karl Bönninger estimates that half of those dismissed are taking legal action, but so far no cases have been resolved in court, and in most cases the court hearing will be delayed for so long that the posts will be filled and the only recompense will be monetary.

In Sachsen-Anhalt, about 250, a quarter of the total redundancies, have been for political offences. Half are thought to be appealing their dismissal. Specific numbers in other states are not available, but in Thüringen around 250 people are likely to be involved, at least a third of whom may be seeking legal redress.

Although the restructuring of universities should have been completed within two years, it has been extended for a third year and may take even longer. To date, only one appeal has been completed, with the court finding in favour of the appellant.

Hans-Ulrich Mönnig, lodged a successful appeal against his dismissal as rector and professor at the University of Architecture and Civil Engineering in Weimar, Thüringen, although the state minister of research, Ulrich Fickel, fought unsuccessfully to overturn the ruling. Despite the experience, a result of a poor personal relationship between the two men, Mönnig believes that commissions are necessary to remove Stasi collaborators from public office and that the courts are capable of ensuring that justice prevails. At the same time, he thinks that the hearings and decisions should be open to public scrutiny and that the proceedings should be monitored by a qualified jurist.

\section{Alison Abbott}

\section{Max Planck opens marine institute}

\footnotetext{
Munich. The Max Planck Society, which funds science research institutes throughout Germany, this month opened its 57th variety - the Max Planck Institute for Marine Microbiology in Bremen. The new institute has two directors, and by 1996 plans to have a staff of 100 , including 20 scientists. The research will focus on bacterial processes in marine environments.

Alison Abbott
}

\section{Chinese scientist arrested for entrepreneurial spirit}

Beijing. A Chinese scientist was arrested and thrown in jail for seven days by local authorities for his role in running a factory based on a product invented in his laboratory. The incident, which occurred in July, reflects the considerable hostility in parts of the country towards efforts by Communist Party leaders to support high-technology enterprises as a way of strengthening the nation's economy.

Zhang Shu-Lin, the 52-year-old director of the Jingzhou Kangbao New Technology Research Institute in Hubei Province in central China, visited Xiangfan City in Hubei to meet officials from the local hightechnology development bureau planning a factory to manufacture a powerful detergent he had developed in his laboratory. Zhang had created a similar business in 1987 in cooperation with one of the city's neighbourhood committees, but Fandong government officials were jealous of the factory and after three years their opposition forced Zhang to quit as manager and bankrupted the company.

Since then, the State Science and Technology Commission has begun to encourage scientists to pursue commercially useful ideas, increasing government funding for such efforts. But its campaign has met with mixed success in much of the countryside outside the capital and selected enterprise zones in southern China. In those regions, the legacy of the 10-year Cultural Revolution, with its fervent anti-intellectualism, remains strong.

That attitude, combined with concern that the new factory posed unwanted com- petition for local state-run enterprises, apparently led to Zhang's arrest on 3 July. Forcibly dragged from his temporary residence by Fandong District police, Zhang was handcuffed and paraded through the streets of the city amidst taunts of being "a stinking intellectual and an inventor".

While in prison, Zhang learned that his arrest resulted from an audit of his factory conducted two years earlier that had angered local authorities. Fortunately for Zhang, his situation was brought to the attention of the State Science and Technology Commission in Beijing, which managed to win his release on 10 July.

"This case is an example of what can happen when someone takes advantage of the increased opportunities for commercial activity in China and incurs the envy and anger of local officials", says Richard Dicker, a lawyer with Human Rights Watch in New York. "It offers a small but chilling insight into the many restrictions that exist on scientific activity in China."

The incident might have escaped notice had not the local party chief, Yang BingQing, learned about Zhang's arrest a few weeks later. Yang promptly apologized to Zhang and promised to pursue those responsible. An investigation is continuing.

The Chinese press have decried the episode as demonstrating how much remains to be done to sell the government's message that the nation respects scientific talent and the fruits of its labour. Clearly, what is needed is an ongoing educational campaign about the value of knowledge.

You Qin Li

\section{Scavengers undermine Indian incinerator}

New Delhi. India's legions of rag-pickers have foiled the country's first waste incineration plant, causing it to close without having produced any electricity. The government is seeking $\$ 10$ million in damages from M/S Volund, the Danish contractor responsible for designing, building and operating the plant.

The waste plant, commissioned in 1988, was designed to generate $4 \mathrm{MW}$ of electricity by burning 300 tonnes of waste daily. But neither the government nor the contractor took into consideration Delhi's 8,000 ragpickers, who systematically retrieve reusable items such as wood, plastics, paper and cloth from municipal landfills. Unfortunately, once such combustible garbage is removed, the remains - mostly rotten vegetables and cooking wastes that do not easily burn - are not sufficient to operate the plant.
The Danish company was supposed to operate the plant for one year before handing it over to India's Department of Nonconventional Energy Sources (DNES), but engineers tried unsuccessfully for 18 months to get the plant working. DNES officials say that the company's engineers tested the quality of Delhi's garbage and found it adequate, and the government has asked for $\$ 10$ million to recover its investment.

Apart from the issue of the garbage, environmentalists have opposed the plant because it does not contain a flue-gas cleaning system to reduce levels of dioxin being emitted. The Danish company has been criticized for ignoring the fact that several municipal incinerators emitting high levels of dioxin were shut down in the Netherlands at the same time as the contract with India was being negotiated.

K.S. Jayaraman 